\title{
Chilli Pepper (Capsicum Spp.) Diversity, Production and Fungal Contamination Management in Benin
}

\author{
Nicéphore M. Glodjinon1, Agossou P. Noumavo1,2, Brice A. M. Ohin'1, Noel S. Tovide1, \\ Fatiou Toukourou ${ }^{1}$, Lamine Baba-Moussa ${ }^{2}$, Aly Savadogo ${ }^{3}$, Farid Baba-Moussa ${ }^{*}$ \\ ${ }^{1}$ Laboratoire de Microbiologie et des Technologies Alimentaires, Faculté des Sciences et Techniques, Université d’Abomey-Calavi, \\ Abomey-Calavi, Bénin \\ ${ }^{2}$ Laboratoire de Biologie et de Typage Moléculaire en Microbiologie, Faculté des Sciences et Techniques, Université \\ d'Abomey-Calavi, Abomey-Calavi, Bénin \\ ${ }^{3}$ Laboratoire de Biochimie et Immunologie Appliquée, Unité de Formation et de Recherche en Sciences de la Vie et de la Terre, \\ Université Ouaga I Professeur Joseph Ki-Zerbo, Ouagadougou, Burkina Faso \\ Email: ^fbmouss@yahoo.fr
}

How to cite this paper: Glodjinon, N.M., Noumavo, A.P., Ohin, B.A.M., Tovide, N.S., Toukourou, F., Baba-Moussa, L., Savadogo, A. and Baba-Moussa, F. (2021) Chilli Pepper (Capsicum Spp.) Diversity, Production and Fungal Contamination Management in Benin. American Journal of Plant Sciences, 12, 1859-1879.

https://doi.org/10.4236/ajps.2021.1212129

Received: November 4, 2021

Accepted: December 21, 2021

Published: December 24, 2021

Copyright $\odot 2021$ by author(s) and Scientific Research Publishing Inc. This work is licensed under the Creative Commons Attribution International License (CC BY 4.0).

http://creativecommons.org/licenses/by/4.0/

\section{(c) (i) Open Access}

\begin{abstract}
The present study was carried out in the form of a survey with the aim of listing and describing the technical itineraries of production, storage and conservation used in six departments of high production of chilli pepper in Benin. The survey was conducted on the basis of a questionnaire in the six departments of Benin: Ouémé, Plateau, Atlantic, Littoral, Zou and Collines. The survey collected information on the socio-economic characteristics of producers, the varieties of chilli pepper grown, and the current technical itineraries used for the production, storage and conservation of chilli pepper. On the other hand, it also gave an idea of the constraints that prevent the production of chilli pepper of good sanitary quality. The results of this survey show that three varieties of chilli peppers are the most produced and consumed in Benin. These are the Gbotakin variety (Capsicum chinense), the Afundja variety (Capsicum annuum) and the Danhomètakin variety (Capsicum frutescens). The technical itineraries related to the cultivation of these chilli peppers varieties are the same in the six study departments. Unfortunately, their contamination sometimes starts at the nursery stage, passing through the field where other contaminants are added and develop until harvest. After harvest, contamination can continue in storage and finally reach the consumer if proper measures are not taken. The inappropriate or inadequate use of phytosanitary products in the chilli pepper industry is also a source of illness for consumers of this vegetable fruit. Training of producers
\end{abstract}


on the best technical itineraries for the production and storage of chilli peppers is essential to revitalize and develop this sector by improving the sanitary quality of the chilli peppers produced in Benin.

\section{Keywords}

Chilli Pepper, Capsicum Spp., Technical Itineraries, Fungal Contamination, Benin

\section{Introduction}

The chilli pepper (Capsicum spp.) is a vegetable plant, belonging to the Solanaceae family, which includes other species such as tomato (Solanum lycopersicum), potato (Solanum tuberosum), tobacco (Nicotiana tabacum) and eggplant (Solanum melongena) [1]. Native to South and Central America, chilli pepper is cultivated throughout the world. Its importance is related to its nutritional and medicinal value due to its richness in vitamins $\mathrm{C}$ and $\mathrm{E}$ and its antioxidant properties, elements that help to prevent cardiovascular disorders, cancers and cataracts [2] [3] [4]. The chilli pepper has a different varietal diversity in several characteristics, including fruit shape, size and color, adaptation to biotic and abiotic stresses, and productivity level [5] [6]. Worldwide, the consumption of chilli pepper fruits, probably classified as one of the first spices or food additives, is constantly increasing [4] [7]. FAO statistics estimate global chilli pepper production at 38,415,621 tons in 2016 for a sown area of 3,737,635 ha [8]. In Africa, Nigeria, Egypt and Ghana have a regular production that is found on the international market [9]. The total production in 2016 in Benin was 176.536 tons [8] and is still growing to this day.

Despite its importance in the agri-food and agro-economic sectors in Benin, chilli pepper unfortunately remains a preferential source of contaminants, including molds, due to poor production, storage and conservation practices adopted by producers. Also, due to the many constraints facing its production, chilli peppers yields are still low and hardly exceed 1.5 tons/ha [10] compared to a potential yield of 15 tons/ha [11]. These constraints are related to, among other things, the lack of production infrastructure in lowland areas, the poor performance of farmers' production techniques, the absence or unsuitability of commercially available selected varieties, the susceptibility of traditional varieties to diseases and pests, and finally the absence of technical itineraries developed for cultivation [4] [6].

It is within this framework that the present study aims to list and describe the different varieties of chilli peppers grown and consumed, to investigate the technical itineraries of production, storage or conservation of chilli peppers and other data relating to the chilli pepper sector in Benin through a collection of information from producers. 


\section{Materials and Methods}

\subsection{Study Area}

A survey was carried out in the different Districts of Benin in order to collect information on the knowledge, the different forms of uses, the traditional practices of production, the processes of storage or conservation. It also helped to identify the importance of chilli pepper in the diet of the Beninese population without forgetting to identify the different techniques (traditional and modern) used to prevent and control fungal contamination of chilli pepper in the field and after harvest. For this purpose, a questionnaire was developed taking into account the different ethnic groups, religions, age, gender and other specific selection criteria. The survey lasted 3 months and concerned mainly chilli pepper producers. Six departments where chilli pepper is produced were visited. These were the departments of Ouémé, Plateau, Zou, Atlantique, Littoral and Collines (Figure 1). In each department, at least two Districts were visited and in each

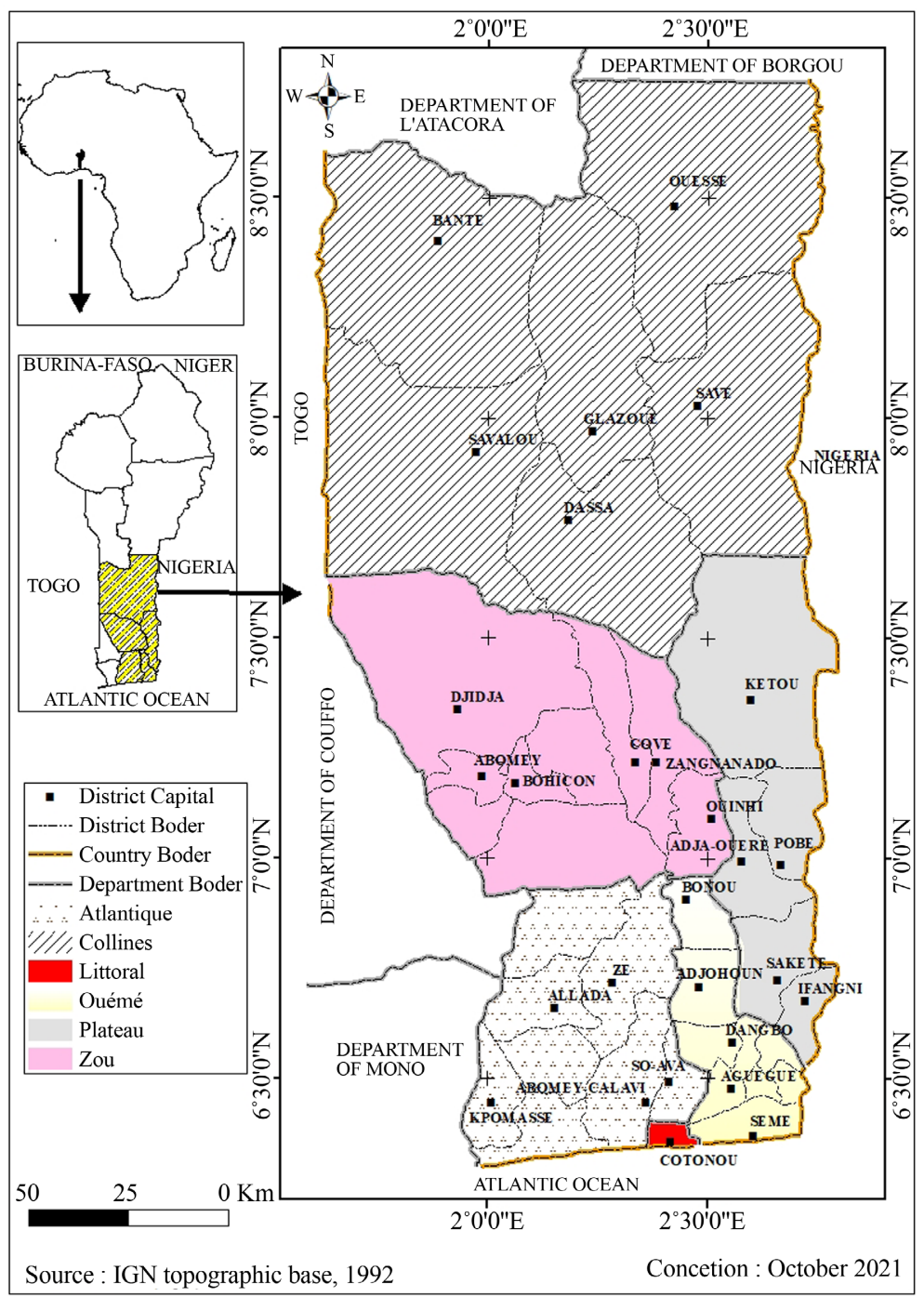

Figure 1. Geographical location of the municipalities surveyed. 
District, at least two villages were visited to interview producers who were selected at random. The only exclusion criterion was a minimum age of 15 years. In total, 240 people were surveyed. The information collected from respondents was expressed as percentages. In each District, the heads of the Regional Agricultural Production Centers (CERPA) were approached to identify the villages where chilli pepper was produced.

\subsection{Data Collection}

Data were collected using participatory research evaluation tools and techniques such as direct observation, producer groups, farmer organizations and individual interviews. These participatory research evaluation tools based on a questionnaire have been used in similar studies [12] [13]. Interviews were conducted in the local dialect spoken by producers with the help of interpreters in some areas. Some key questions were considered throughout the questionnaire. These included questions related to cultivation methods, storage equipment, storage and preservation processes, the type of processing done before or during storage of the chilli pepper, contamination patterns, and methods of protection against contamination. Questions were also asked about the risks associated with endogenous consumption of chilli peppers, knowledge of mold contamination, and the criteria used to visually identify the presence of mold on chilli pepper.

\subsection{Analyses of the Survey Data}

The survey forms were processed manually and the data were encoded using Microsoft Excel 2016. In order to achieve the objectives of the study, descriptive statistical analysis was performed on these data according to the different parameters evaluated (age, gender, ethnicity, level of education, cultivation practices, storage or preservation practices, perception on molds) using SAS (Statistical Analysis System) software version 8.1.

\section{Results and Discussion}

\subsection{Socio-Economic Characteristics of Respondents}

Socio-economic characteristics and data on the varieties of chilli peppers grown in the study area were presented in Table 1.

This study was conducted in Benin and involved 240 producers who were surveyed in the districts, arrondissements and villages of the six departments mentioned, namely: Ouémé, Plateau, Zou, Collines, Atlantique and Littoral. The districts of Adjohoun, Dangbo, Aguégué, Missérété, Ifangni, Kétou, Sakété, Abomey, Bohicon, Dassa, Savè, Savalou, Cotonou, Semè Kpodji, Abomey-Calavi and Allada were surveyed in the six departments. The lowest number of respondents per department was 25 and was recorded in the Littoral Department, while the highest number of respondents (60) was recorded in the Ouémé Department. The largest total area cultivated by a producer is 3 hectar and is obtained in the department of Ouémé precisely in the district of Adjohoun, in Hlankpâ 
Table 1. Socio-demographic characteristics of respondents.

\begin{tabular}{|c|c|c|c|}
\hline Variables & Characteristics & $\begin{array}{c}\text { Percentage } \\
(\%)\end{array}$ & Number \\
\hline \multirow{2}{*}{ Gender } & Man & 70.10 & 168 \\
\hline & Woman & 29.90 & 72 \\
\hline \multirow{3}{*}{ Age } & 15 - 25 Years & 15.55 & 37 \\
\hline & $26-35$ Years & 34.27 & 82 \\
\hline & $35-72$ Years & 50.18 & 120 \\
\hline \multirow{4}{*}{ Education } & None & 70.00 & 168 \\
\hline & Primary school & 24.00 & 58 \\
\hline & Secondary school: undergraduate & 4.00 & 10 \\
\hline & Secondary school: second cycle & 2.00 & 5 \\
\hline \multirow{8}{*}{$\begin{array}{l}\text { Ethnic } \\
\text { Groups }\end{array}$} & Fon & 40 & 40.02 \\
\hline & Goun & 25 & 24.55 \\
\hline & Nago & 8 & 8.17 \\
\hline & Wémè & 11 & 11.31 \\
\hline & Tori & 5 & 4.90 \\
\hline & Idacha & 4 & 3.80 \\
\hline & Yoruba & 4 & 4.13 \\
\hline & Mahi & 3 & 3.12 \\
\hline \multirow{7}{*}{$\begin{array}{l}\text { Sensory } \\
\text { properties }\end{array}$} & Burning taste & 33.00 & 79.2 \\
\hline & Aroma & 10.00 & 24 \\
\hline & Color & 7.00 & 16.8 \\
\hline & Burning taste and Aroma & 11.00 & 26.4 \\
\hline & Burning taste and Color & 14.00 & 33.6 \\
\hline & Aroma and Color & 7.00 & 16.8 \\
\hline & Burning taste, Aroma and Color & 18.00 & 43.2 \\
\hline \multirow{3}{*}{$\begin{array}{l}\text { Training } \\
\text { courses } \\
\text { followed }\end{array}$} & Production & 80.00 & 192 \\
\hline & Storage & 12.00 & 29 \\
\hline & Conservation & 8.00 & 19 \\
\hline
\end{tabular}

while the smallest cultivated area $\left(50 \mathrm{~m}^{2}\right)$ is obtained in the department of Littoral precisely in Cotonou.

This enormous difference in the area planted can be explained by the im- 
mense availability of land and swamps in the Ouémé Valley, but also by the enthusiasm of villagers for chilli pepper cultivation in this very rural area where agriculture is practiced to a great extent, unlike Cotonou, which is a highly populated urban area where agriculture is almost no longer practiced because of the evolving lack of suitable land for agriculture.

The results of this survey show that not all the producers surveyed belong to a farm group. In fact, only $30 \%$ of the respondents belong to a group and the other seventy don't belong to any agricultural group. This could be explained by the unavailability of producers in these rural areas due to cultivation practices, which they mistakenly consider more important than the practical training they should receive in groups to improve the quality of their production. Also, only $28 \%$ of producers have received training, compared to $72 \%$ who acknowledge that they have not received any training on technical production, storage, conservation and even on the health risks associated with the consumption of poor quality chilli peppers. Of the $28 \%$ of respondents who had received training, $80 \%$ acknowledged having received training on the technical production of chilli peppers, $12 \%$ on the technical storage of chilli peppers and $8 \%$ on the technical conservation of chilli peppers. It should be noted that no producer has received training on the risks related to the sanitary quality of chilli peppers. This confirms the lack of monitoring of producers by certain competent structures of the Ministry of Agriculture, Livestock and Fisheries (MAEP) such as the National Agricultural Research Institute of Benin (INRAB), the Central Laboratory of Food Safety (LCSSA) and the Beninese Agency of Food Safety (ABSSA), which could accompany producers and train them on the sanitary risks of foodstuffs such as chilli pepper. These trainings are very important because they would allow producers to have an idea of the relationship between the consumption of agricultural products of poor sanitary quality and the risks of food-borne diseases that could result from them, such as intoxications, food-borne toxi-infections, etc. These trainings would force producers to become aware of the risks and to respect the technical itineraries of production, storage and conservation in order to obtain finished products of very good sanitary quality.

\subsection{Technical Itineraries of Chilli Pepper Production}

\subsubsection{Varieties Grown in Benin}

The results of the survey show that three varieties of chilli peppers are produced and consumed in Benin. These are round varieties called Gbotakin in the local Fon language (Capsicum chinense), long varieties called Afundja in the local Fon language (Capsicum annuum) and very small varieties called Danhomètakin in the local Fon language (Capsicum frutescens) (Figure 2). The variety most produced by respondents is the Gbotakin variety (42\%), followed by the Afundja variety $(28 \%)$, the Danhomètakin variety $(14 \%)$, the mixture of Gbotakin and Afundja varieties (10\%), and finally the mixture of the three chilli peppers varieties (6\%) (Figure 3). 


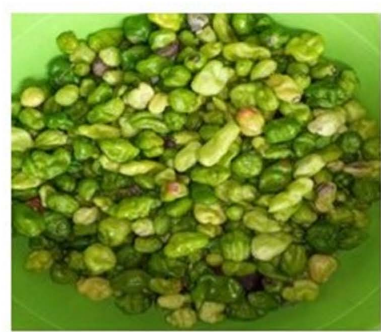

[A]

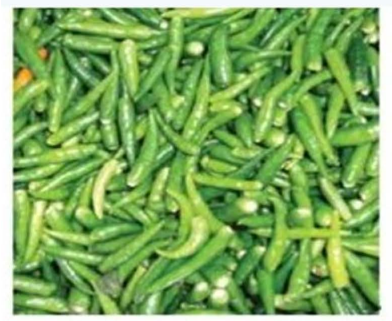

[B]

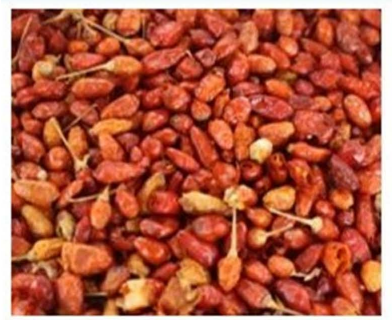

$[\mathrm{C}]$

Figure 2. Different varieties of chilli pepper grown in Benin. [A] Variety of fresh Gbotakin chilli pepper (Capsicum Chinense); [B] Variety offresh Afundja chilli pepper (Capsicum annum); [C] Variety of dried Danhomètakin chilli pepper (Capsicum frutescens).

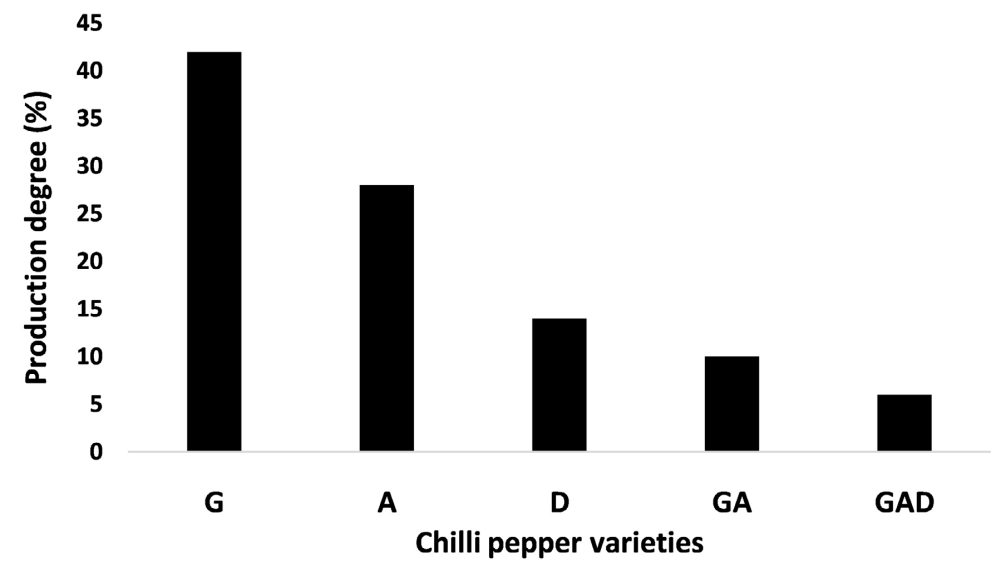

Figure 3. Production degree of chilli pepper varieties by farmers. [G]: Gbotakin (C. chinense), [A]: Afundja (C. annuum), [D]: Danhomètakin (C. frutescens), [GA]: A and G, [GAD]: $\mathrm{G}$ and $\mathrm{A}$ and $\mathrm{D}$.

The varieties Gbotakin (Capsicum chinense), Afundja (Capsicum annuum) and Danhomètakin (Capsicum frutescens) are among the most cultivated and consumed chilli pepper species generally cited in the literature in Benin [4] [6] [14]. These results confirm those of Fondio [7] who stipulate that these chilli 
pepper species have a wide range of phytochemical compounds with well-known antioxidant properties and are the best known varieties in the world. The Gbotakin variety is recognized by the respondents $(100 \%)$ as the most lucrative variety. The study also found that the chinense group of chilli peppers. (Gbatakin) is the most popular among consumers because of the presence of aroma in its fruits. Unfortunately, the shelf life of its fruits is very poor compared to chilli peppers of the annuum (Afundja) and frutescens (Danhomètakin) groups [15]. The chilli peppers are produced in home gardens, agricultural development perimeters, in pure culture or in association with other crops such as tomato (Solanum lycopersicum L.), maize (Zea mays L.), groundnut (Arachis hypopaea), cowpea (Vigna unguiculata subsp. Unguiculata), soybean (Glycine max), cassava (Manihot esculenta), and yam (Dioscorea alata L.) varieties, etc.

The criteria of preference or varietal selections, listed by the producers are mostly (79.80\%) of agronomic nature. Among them, the most important are: resistance to pests $(30.42 \%)$, high productivity $(12.34 \%)$, resistance to diseases $(14.68 \%)$, resistance to the early fall of organs (leaves, flowers and fruits) of the plant (13.06\%), adaptability to any type of soil (7.23\%), tolerance to drought (13.27\%) and others (9\%). These results are in good agreement with Orobiyi [6] and Reifschneider [16] who showed that the choice of a variety depends on its ability to withstand environmental constraints, pests and plant diseases. According to Mnahoncakova [17], the examination of the variability of fruit-related traits to select appropriate germplasm has been demonstrated in several species of chilli pepper (Capsicum spp.) [18] [19] [20] [21]. It also demonstrated the significant difference existing between several varieties of chilli peppers due to color, maturity degree and fruit shape characterized as campanulate, polyhedral, ovoid, round, almost round, linear, triangular, rectangular, elongated, etc. [17]. The genetic diversity of hot chilli pepper traits based on phenotypic and molecular descriptors has been studied by several authors [22] [23] [24]. However, most of them have focused on morphological descriptors of fruits and fewer have examined a wide range of morpho-agronomic descriptors including both qualitative and quantitative traits [6] [21] [25].

\subsubsection{Chilli Pepper Cultivation Practices in Benin}

In general, there are four chilli pepper growing systems: rainfed, flooded, lowland and irrigated. In Benin, the average farm size is 1.13 ha per producer, with the smallest cultivated area being $15 \mathrm{~m}^{2}$ and the largest 3 ha. The cultivation operations carried out in the field include: preparation of the land, installation and management of the nursery, planting of the seedlings, management of the crop, harvesting and packaging, conservation and storage of the products. The producers (market gardeners or farmers) often work individually. However, in areas of high production, particularly in valleys and urban or peri-urban areas, there are farmers' organizations (village groups). These are production or service cooperatives. The analysis of fruit ripening time showed that there is no relationship between the ripening time of varieties and the type of chilli pepper (Capsi- 
cum annuum, Capsicum chinense and Capsicum frutescens) grown. According to the producers, the duration of chilli pepper ripening is influenced by the humidity and fertility of the soil and by the condition of the seeds sown. Regarding soil fertilization, only a few producers use organic fertilizers such as chicken droppings, cow dung, compost and peanut or cowpea hulls and Mucana pruriens leaves as green manure to increase the productivity of the chilli peppers they grow. Most producers use chemical fertilizers to produce chilli pepper, which have harmful consequences for the environment and the health of producers and consumers. As for phytosanitary protection, integrated pest control methods are not well known by producers. These means of control must be encouraged to protect not only the crops against pests and pathogens but also the environment and the health of the populations for a sustainable agriculture. It is also important to note that at the country level, women actors of the sector are more active in the marketing and production of chilli pepper than men. They are involved in every stage of production. It is a crop that does not require much physical effort and allows women to meet their daily needs. The cultivation practices related to the cultivation of the three chilli pepper varieties studied are the same in the six study departments. They include a nursery stage, transplanting of young plants, maintenance of the crop by weeding, fertilization and irrigation for off-season crops and sometimes even for recession crops, and finally harvesting. Generally, this culture is done in four stages of which the most delicate is the first stage, which is the nursery. The success of a chilli pepper crop depends on the quality of the plants from the nursery. Indeed, the time of the nursery varies from 21 to 35 days according to the variety, the type of ground, the period and the zone of production. The stage of nursery generally passes by the supply of seeds, the installation of the nursery, the calculation of the surface and quantity of seeds and the types of nursery to be carried out. These different steps are described in summary as follows:

In traditional chilli pepper production, several varieties are grown simultaneously and the seeds are taken from the fruits of the previous harvest. This self-production of seeds is not recommended because it reduces the performance (yield, shape, color, etc.) of the variety thus multiplied. The setting up of a nursery involves a succession of operations such as the delimitation of the area, the choice of the type of nursery, the preparation of the plot, the fertilization of the soil, the sowing and the maintenance. A nursery of $4 \mathrm{~m}^{2}(1 \mathrm{~m} \times 4 \mathrm{~m})$ receives 15 to $20 \mathrm{~g}$ of seeds and allows to plant 1 kanti of culture (approximately $400 \mathrm{~m}^{2}$ ). A nursery of 100 to $120 \mathrm{~m}^{2}$ receives 350 to $500 \mathrm{~g}$ of seeds and allows to plant 1 ha of culture $\left(10.000 \mathrm{~m}^{2}\right)$. The nursery can be a ground level bed or a stilted container. The tray on stilts is recommended for vegetable plots infested with nematodes, fungi or bacteria. The nursery bed should be flat, sandy, well drained and rich in organic matter. It should be installed in a sunny and ventilated area of the field, sheltered from the wind and as close as possible to a water source to facilitate watering. The second step is transplanting. This step consists in marking out the seedlings on the plot to be transplanted with strings and stakes while 
avoiding holes too deep of 3 to $4 \mathrm{~cm}$. Then select vigorous seedlings and pull them out with the clod of earth around the roots. Pack the soil well around the roots without damaging the collar of the seedling and water if possible immediately after transplanting. The third step is the maintenance of the crop, which consists of sacro-buttage, irrigation, phytosanitary protection and fertilization of the soil. The fourth and last stage is the harvest of the fruits which normally starts 3 months after the transplantation in several times ( 3 - 5 harvests). The fruits mature progressively taking a deep red color (blood color). The fruits on the bright and sunny sides ripen first compared to those in the shade and inside the foliage. Partial dehydration of the fruits on the plants is recommended because the color stability in the chilli pepper is better when harvested late. As maturity increases, the dry matter content increases in parallel, as well as the intensity of the color. Harvesting should be done early in the morning and should be avoided during or just after the rains. When harvesting the fruits, care should be taken to hold the stems firmly and the fruits should be pulled up gently, breaking at the base of the stem and avoiding damage to the fruits and plants. Unripe fruits are harvested with their stalks to prolong their ripening. Harvested fruit is immediately sorted. Rotten, broken or infested by fly larvae are eliminated. The fruits are then sold fresh or dried for off-season marketing.

\subsubsection{Growing Conditions and Soil Fertilization}

The chilli pepper is generally planted as an annual crop. It can be planted all year round, but the best harvests are obtained when the fruit sets during the cool periods of August, December and January, at $18^{\circ} \mathrm{C}-25^{\circ} \mathrm{C}$. The periods too fresh, below $16^{\circ} \mathrm{C}$, slow down the development of the plant. Therefore, the best time for nursery and cultivation is from March to December for the study area. The floodplain areas allow for off-season production in the dry season from January to March. The supply of chilli pepper on the national market depends on the cultivation periods:

- From August to December, markets are supplied by the harvest of rainfed crops;

- From December to May, the relay is taken by the off-season harvests of flood crops (Ouémé valleys) and irrigated crops (Littoral, Atlantic and Plateau departments);

- Between January and May, imports of chilli pepper from Nigeria, Togo and Ghana are added to local production.

The fertilization of the soil is fundamental for a better productivity of the chil-

li pepper crops and varies from one soil to another:

- On very sandy soils, well-decomposed organic manure (chicken droppings, cow dung, compost, sheep droppings, etc.) should be applied.

- On soils poor in organic matter and fine elements and very sandy on the surface, a complex mineral fertilizer NPK must be applied in addition to the organic manure.

- On a new field, mineral fertilization can be applied after washing when the 
plants become vigorous enough to support the fertilizer.

Fertilizer application methods differ according to the type of nursery:

- In nursery on a bed, incorporate by digging $2 \mathrm{~kg} / \mathrm{m}^{2}$ of organic fertilizer (compost, chicken droppings or well decomposed cow dung); then, depending on the type of soil, incorporate 20 to $50 \mathrm{~g} / \mathrm{m}^{2}$ of mineral fertilizer with a rake and level again.

- For nurseries in containers, mix compost at a rate of $1 / 3$ compost for $2 / 3$ sterilized soil.

\subsection{Nutritional Importance and Sensory Profile of Chilli Pepper}

The chilli peppers, used as a condiment or spice, are well known in Benin by women, men and different ethnic groups. This observation confirms that of Fett [26] who indicated that chilli peppers are the best known spices and condiments. Women (60\%) are more consumers of chilli pepper than men (40\%). These results confirm those of Amiot-Carlin [27] and Blanck [28] who indicated that fruits and vegetables are more consumed by women. The different ethnic groups regularly consume chilli pepper. These results are in agreement with those of Amiot-Carlin [27] who noted the importance of ethnicity (Hispanic, Asian or African-American) in the consumption of vegetables through an American study. These results are also consistent with those of Johnson [29] and Rodriguez-Burruezo [30] who discussed the place of chilli pepper in Indian cuisine and its growing importance in ethnic restaurants in Europe and Africa. According to the survey results, chilli pepper is consumed daily for its nutritional (65\%) and sensory (35\%) properties, among which the hot taste is the most important, followed by its aroma. Sauces are the most frequent modes of consumption (56.02\%) followed by grilling (28.98\%) and the treatment of diseases by herbalists (15\%) because of its medicinal properties that are an integral part of the values attributed to it. Constipation would be at $16 \%$, the most treated affection by the varieties of chilli pepper followed by gastroenteritis (10\%). This information collected on the chilli pepper justifies its importance and its rank among the vegetable crops. The aroma, fragrance or smell of chilli pepper always stimulates its consumption according to the respondents. These results support those of Avaloz De La Cruz [31], who in a sensory analysis showed that the color, pungency and aroma of fresh or cooked chilli pepper fruits regardless of variety were the descriptors that had a positive influence on the general acceptance of a food [29] [32]. The main culinary modes of chilli pepper remain sauces and grilling which are characteristic of African peoples with a preference for hot (cooked) dishes. One of the main reasons for consuming chilli pepper is the pungent and irritating taste that gives a hot sensation in the mouth. In fact, chilli pepper is usually consumed in several forms. It is consumed as fresh fruit or as fresh fruit transformed into paste just after harvesting, but also as dried fruit transformed into powder for the preparation of different foods. These results are in good agreement with those of Reifschneider [16] who showed that chilli pepper is consumed in fresh, dried, whole or powdered form all over the world. According to the respondents, chilli pepper 
is also known as a taste enhancer for local foods and dishes consumed in Benin [4]. Indeed, the main interest of chilli pepper lies in its physicochemical composition which varies according to varieties and environmental conditions [33] [34]. Its richness in antioxidants among which is capsaicin is actually the property that gives it a great neutraceutical value [35] [36] [37]. In many cases, fruit coloration with the presence of natural dyes in the flesh also determines fruit antioxidant activity [17] [38]. According to Kopta [39], in the hottest year of 2018, most cultivars responded by increasing fruit weight and consequently yielded higher total yield per plant with very good sources of vitamin $C$ for all chilli pepper varieties studied. Indeed, the potential yield of a chilli pepper crop depends on the variability of fruit number, size, fruit size and other parameters per plant such as average fruit weight. Also, capsaicin in chilli pepper fruits has been shown to be distributed throughout the fruit with a higher concentration found in the placental tissue of the seeds and is used to treat severe chronic diseases, migraines, osteoarthritis or to lower cholesterol levels [38] [39] [40]. This capsaicin content is further influenced by several factors such as water stress level, rainfall, plant age, fruit size, increase in cultivation temperature, solar radiation [38] [41] [42].

\subsection{Contamination of Chilli Pepper in the Field in Benin}

The results of this survey show that molds are the most known contaminants of field grown chilli pepper. According to growers, various colors of molds are observed directly in the field and after harvest on the three varieties of chilli pepper grown in the study area (Figure 4). These are generally gray, white, black, greenish-black, yellow, green; blackish; light blue; beige and greenish. $90 \%$ of the respondents admitted to having a general knowledge of molds, while $10 \%$ had never heard of them. Also, of the respondents who knew about molds, $84 \%$ admitted to seeing them in the field on the varieties they grew and the rest $(16 \%)$ had never seen them in the field. In addition, some molds produce mycotoxins,

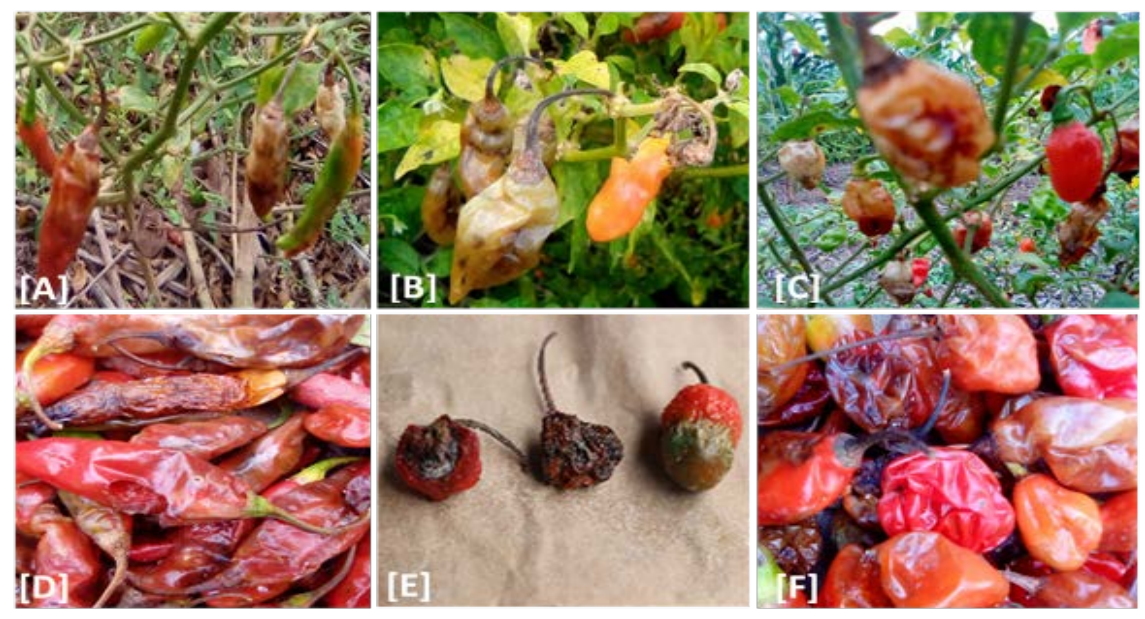

Figure 4. Some diseases of fungal origin. [A]-[C] Fungal diseases of chilli pepper in the field; [D]-[F] Post-harvest fungal diseases of chilli pepper. 
which are the products of their secondary metabolism. Unfortunately, almost all of the respondents (90\%) do not know anything about mycotoxins and do not know that there is a relationship between molds and mycotoxins. It also appears from the information that aflatoxin is the mycotoxin known by all the respondents (100\%) who have knowledge about mycotoxins.

This low level of knowledge of producers about molds and mycotoxins can be explained in part by the very low level of education or literacy of producers. On the other hand, it is due to the lack of training given to producers on cultivation practices, storage or conservation procedures and health risks. Indeed, $70 \%$ of the respondents have never received any formal training, compared to $30 \%$ who have. Of those who have received training, $24 \%$ have primary education, $4 \%$ have lower secondary education and the remaining $2 \%$ have upper secondary education. In fact, the chilli pepper is particularly sensitive to diseases such as viruses caused by aphids and thrips, but also fungal diseases such as aspergillosis, Alternariosis and Fusariosis etc. These results are consistent with those of Orobiyi [6] and Fondio [43] who showed that chilli peppers varieties are victims in the field by fungal diseases, bacterial diseases, viruses but also pests. Crop rotation, which is carried out by alternating the cultivation of chilli pepper with crops of other botanical families such as tomato (Solanum lycopersicum), eggplant (Solanum melongena), nightshade (Solanum nigrum) etc., helps to break the life cycle of crop pests, diseases [11] [44]. The presence of molds on chilli peppers varieties in the field is due to poor cultural practices used by some producers, poor growing conditions and use of phytosanitary products unsuitable or sometimes inappropriate for the cultivation of chilli pepper [7] [44]. Once contaminated in the field, contamination continues after harvest, during transport, and during storage [45]. Finally, inappropriate storage or preservation processes used and the unsuitability of some varieties for preservation are also responsible for attacks by microorganisms especially molds [4] [34] [37].

\subsection{Field Protection and Pest Control of Chilli Pepper}

The chilli pepper is confronted with many phytosanitary problems during its cycle. According to some producers, the aqueous extract of garlic is the solution they use as an insecticide to control certain vectors such as aphids and caterpillars responsible for plant diseases such as anthracnoses and others. The results of the survey reveal that it takes about 15 to 20 liters of aqueous solution of garlic extract to treat $400 \mathrm{~m}^{2}$ of crop depending on the age of the plants. Also, the best way to control most of the diseases of chilli pepper plants is the elimination of infection vectors such as viruses, bacteria, aphids, white flies and especially molds from the nursery stage to the field before fruit maturity. Other producers, proceed to the rotation of culture which also allows to fight against certain diseases like nematodes. Crop associations are also adopted by the producers. It is about the realization of the culture of the chilli pepper with other cultures as the corn (Zea mays L.), the bean (Phaseolus vulgaris), the groundnut (Arachis hypogaea), the manioc (Manihot esculenta), certain vegetables of which Vernonia 
(Vernonia amygdalina), crin-crin (Corchorus olitorius), okra (Abelmoschus esculentus), African eggplant plants (Solanum macrocarpon) and other vegetable crops suitable for association with chilli pepper. In addition, the majority of producers use phytosanitary products to control the most common pests and diseases in the nursery and in the field (Figure 5).

Most of these products are not approved by the Beninese Government. According to the results of the surveys, $72 \%$ of these products are bought by producers in the markets: Azowlissè Market (District of Adjohoun), Malo Market (District of Dangbo), and Ikpinlè Market (District of Ikpinlè), but $28 \%$ of them are also bought by producers in the formal structures of the Ministry of Agriculture, Livestock and Fishery, such as BENIN SEMENCE. Moreover, it would be a question for the producers, to use appropriate technical itineraries for the culture of chilli pepper, respecting the use of approved phytosanitary products, recommended by the competent structures of the Ministry of Agriculture, Livestock and Fishery as regards market garden products in order to cultivate chilli peppers of good sanitary quality. Indeed, it is recommended, for example, the use of foliar herbicides of low persistence (glyphosate, sulphosate and gluphosinate of ammonium) against the stand of perennial plants before transplanting [46]. Also, weed control is also recommended to effectively control weeds that are alternative hosts for insects and pests responsible for some chilli pepper

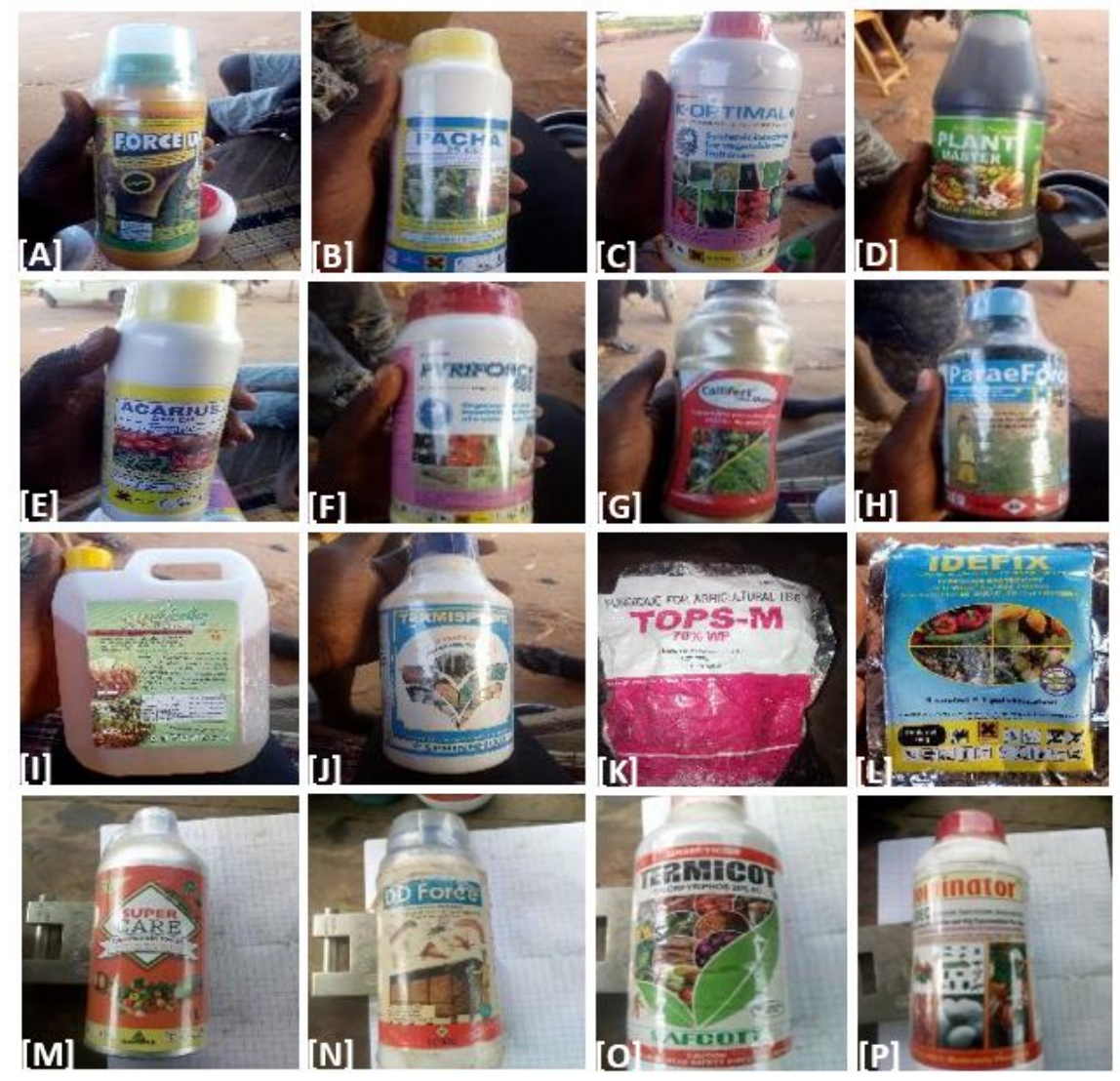

Figure 5. Phytosanitary products used in the chilli pepper production in Benin. 
diseases [4] [6] [46]. The real problem lies in the use of inappropriate or unsuitable phytosanitary products that constitute sources of post-consumption problems given that these chemicals are still found in trace amounts and sometimes even in high doses on the finished products thus presenting health risks for consumers. It is in this context that the main active ingredients used in the agricultural sector differ from one product to another and from the problems encountered by the producer in his field.

For example, this is the case of insecticides used to effectively control insects that attack chilli pepper in the field. According to the research work of Hakmaoui [44], these insecticides specifically consist of the following chemical compounds that vary depending on the insects involved:

- Thrips: Spinosad, formetanate, abamectin ;

- Mites: Dicofol, abamectin, bifentrin;

- Fruit fly: Malathion, deltamethrin, trichlorfon;

- Aphids: Azadirechtin, pyrimicarb, acetamiprid, pyrethroid;

- Root-knot nematodes: Carbofuran;

- Caterpillars, leafminers, flea beetles, yellow bugs: azadirechtin, cypermethrin, lambda-cyhalothrin.

Other chemical compounds are also used to control some common diseases of chilli peppers in the field [11] [44]. These are copper-based chemical compound for the control of bacterial blight, copper-based compound, azoxystrobin and chlorothalonil for the control of anthracnose and finally thiram, cryptonol and previcur-based molecules for the control of crown rot agents.

\subsection{Post-Harvest Storage Methods for Chilli Pepper}

The most difficult aspect of the chilli pepper chain is the post-harvest storage or preservation of chilli pepper fruit for use during the shortage or off-season. The improved storage methods most commonly used by respondents are as follows: 1) Immediately after harvest, wash the chilli pepper fruits and put them on the fire in a pot previously containing red oil. After cooking, put the chilli peppers in a sieve or basket. Then, dry them in an oven or in the sun on a clean bag for 72 hours and pour them into a can and close it hermetically. Indeed, the pepper can be preserved for 9 months thanks to this process of storage without any appearance of contaminants and especially molds. This method is adopted by $40 \%$ of the producers surveyed. 2) The rest, about $60 \%$, adopt the method of conservation in boiling water. This method consists of washing and boiling the chilli peppers for 30 to 40 minutes before drying them in the sun or in an oven at $40^{\circ} \mathrm{C}$ and $70^{\circ} \mathrm{C}$ for better storage. Then, put them in a canister and close tightly and sometimes even in doubled jute bags for a good storage. These methods do not require the use of toxic chemicals for the most part and are without health risk for consumers. Indeed, the work done by Garba [47] and Ohin [48] showed that the bleaching carried out is a very important operation even capital in the conservation of most agricultural products such as peanut seeds (Arachis hypogeae) and hypocotyls of the roast tree (Borassus aethiopum Mart) against microorgan- 
isms that are the main agents of alteration of foods like chilli pepper. As for the drying carried out by heating the chilli pepper in the oven at $40^{\circ} \mathrm{C}$ and $70^{\circ} \mathrm{C}$ or under the sun at room temperature, it has as a capital effect the reduction of free water and partly bound water but also of some physico-chemical and nutritive components of the chilli pepper thus preventing the development of microorganisms of alteration like moulds. These results are in good agreement with those of Kennao [49] who showed that sun or oven drying of chilli pepper with gradual increase in temperature decreases the brightness, redness and yellowing of chilli pepper fruits by degradation of capsaicinoid contents (mainly capsorubin and capsanthin) responsible for the redness of chilli pepper [7] [50] and flavonoids such as glycosides and aglycones of myricetin, quercetin, luteolin, apigenin and kaempferol [51] responsible for the brightness of chilies. On the other hand, the decrease of these major compounds favors the decrease of the antimicrobial activity of chilli peppers against bacteria following the example of species of the genus Bacillus (mainly Bacillus subtilis and Bacillus cereus) and Sarcina lutea, whose development on chilli peppers was not an evidence because of these antibacterial compounds [7] [51]. It is clear that the drying rate decreased with decreasing moisture content. Also, hot air oven drying used during storage is better for good preservation of chilli pepper than sun drying whose variables are not always well controlled. These results are also consistent with those of other authors who indicate a loss of $75 \%$ of ascorbic acid during the drying of chilli pepper [7]. Also, the degradation of vitamin C content in fruit juices was also proved by El-Ishaq [52] due to the high temperature carried out in the process of their manufacture either by appertization or pasteurization for purposes of good storage.

On the other hand, $99 \%$ of the producers surveyed do not practice preservation which is another storage method involving the use of preservatives which are very toxic chemicals and harmful to the health of the consumer. Unfortunately, very few producers have received practical training on storage $(12 \%)$ and preservation (8\%). Awareness-raising should be reinforced by practical training on technical production, storage and conservation methods, without forgetting the health risks associated with the consumption of chilli peppers of poor sanitary quality. The adoption and implementation of advice from these training sessions would certainly enable producers to better support the development of the chilli pepper industry in Benin.

\section{Conclusions}

This work allowed for a descriptive analysis of the knowledge related to the technical production itineraries, storage or conservation of chilli peppers, consumption, culinary and medicinal uses of the varieties of chilli pepper grown and consumed in Benin. We note that the cultivation practices related to the cultivation of these chilli pepper varieties are the same in the six study departments. They include a nursery stage, transplanting of young plants and maintenance of the crop by weeding, fertilization and irrigation for off-season crops and some- 
times even for flood recession crops, and finally harvesting. The chilli pepper is known, regardless of gender and ethnic group, as a food flavor enhancer. It adds value to the organoleptic properties of dishes such as sauces and grills. Unfortunately, its contamination sometimes starts at the nursery stage, passing through the field where other contaminants are added and develop until harvesting, storage or preservation, and finally ending up in the consumers' homes if appropriate measures are not taken. The information collected during this survey will help establish a database on chilli pepper and will certainly contribute to the development of the chilli pepper industry in Benin.

In order to enhance agricultural production, to relaunch the agro-industrial activity of the chilli pepper in Benin and to attract international investors, it would be a question of improving the technical train of the culture since the work of the ground until the harvest and this by activities of researches allowing the reasoning, the optimization and the integrated management of the means of production such as seeds, fertilizers, the phytosanitary products and even water while taking into account the assets already realized by the research in this field.

\section{Acknowledgements}

We thank the Campus France through the Service Cooperation and Cultural Action (SCAC) of the Embassy of France for the financial support provided for this research.

\section{Conflicts of Interest}

The authors declare that they have no conflicts of interest.

\section{References}

[1] FAO/OMS (World Health Organization) (2007) Aliments issus de l'agriculture biologique. Directives concernant la production, la transformation, l'étiquetage et la commercialisation des aliments issus de l'agriculture biologique. Troisième édition. Codex Alimentarius, $32 \mathrm{p}$.

[2] Oboh, G. and Rocha, J.B.T. (2007) Antioxidants in Foods: A New Challenge for Food processors. Leading Edge Antioxidants Research. Nova Science Publishers Inc., 35-64.

[3] Chuah, L.Y.M. and Chee, M.W.L. (2008) Cholinergic Augmentation Modulates Visual Task Performance in Sleep-Deprived Young Adults. Journal of Neuroscience, 28, 11369-11377. https://doi.org/10.1523/JNEUROSCI.4045-08.2008

[4] INRAB (National Institute of Agricultural Research of Benin) (2009) Référentiel technico-économique de la production agricole. Production durable du piment au bénin, 7-47.

[5] Paran, I. and Van der Knapp, E. (2007) Genetic and Molecular Regulation of Fruit and Plant Domestication Traits in Tomato and Pepper. Journal of Experimental Botany, 58, 3841-3852. https://doi.org/10.1093/jxb/erm257

[6] Orobiyi, A. (2016) Etude ethnobotanique, évaluation participative et caractérisations agromorphologique et biochimique du piment (Capsicum annuum L.) au Bénin. Thèse de doctorat, Université d'Abomey-Calavi, Bénin, 1-119. 
[7] Fondio, L., N'zi, J.C. and Kobenan, K. (2015) Comportement agronomique et sanitaire de nouvelles lignées de piment (Capsicum sp.) dans le Sud de la Côte d'Ivoire. Journal of Applied Biosciences, 92, 8594-8609. https://doi.org/10.4314/jab.v92i1.4

[8] FAO (2018) FAOSTAT Database. Food and Agriculture Organization, Rome. http://www.fao.org

[9] FAO (2016) FAOSTAT Database. Food and Agriculture Organization, Rome. http://www.fao.org

[10] MAEP (Minnesota Artists Exhibition Program) (2007) Etude sur le sous-secteur du maraîchage au Sud-Bénin. Rapport Final, 12 p.

[11] Assogba-Komlan, F., Sikirou, R., Sodjinou, E. and Mensah, A. (2009) Production durable du piment au Bénin. Référence technico-économique de la production agricole, $48 \mathrm{p}$.

[12] Adoukonou-Sagbadja, H., Dansi, A., Vodouhe, R. and Akpagana, K. (2006) Indigenous Knowledge and Traditional Conservation of Fonio Millet (Digitaria exilis Stapf, Digitaria iburua Stapf) in Togo. Biodiversity and Conservation, 15, 2379-2395. https://doi.org/10.1007/s10531-004-2938-3

[13] Dansi, A., Adoukonou-Sagbadja, H. and Vodouhe, R. (2010) Diversity, Conservation and Related Wild Species of Fonio Millet (Digitaria spp.) in the Northwest of Benin. Genetic Resources and Crop Evolution, 57, 827-839. https://doi.org/10.1007/s10722-009-9522-3

[14] Akoègninou, A., van der Burg, W.J. and van der Maesen, L.J.G. (2006) Flore analytique de Bénin. Backhuys Publishers, Leiden, 1034 p.

[15] PNUD-BENIN-PANA-1 (2015) Renforcement des capacités des maraîchers des communes de Adjohoun, de Bopa, et de Ouaké sur l'amélioration des techniques de production et de réduction des impacts des risques climatiques sur la culture du piment, Abomey-Calavi, République du Bénin, 35 p.

[16] Reifschneider, F.J.B., Henz, G.P. and Ribeiro, C.S.C. (2009) Brazilian Capsicums: Early Story and Future Prospects. Chronica Horticulturae, 49, 19-21.

[17] Mňahončáková, E., Valný, P. and Horčinová Sedláčková, V. (2020) Morphological Features of Fruits of Various Species of Chilli Peppers. Agrobiodiversity for Improving Nutrition, Health and Life Quality, No. 4, 159-175. https://doi.org/10.15414/agrobiodiversity.2020.2585-8246.159-175

[18] Carvalho, S.I.C., Bianchetti, L.B., Ragassi, C.F., Ribeiro, C.S.C., Reifschneider, F.J.B., Buso, G.S.C. and Faleiro, F.G. (2017) Genetic Variability of a Brazilian Capsicum frutescens Germplasm Collection Using Morphological Characteristics and SSR Markers. Genetics and Molecular Research, 16, Article No. gmr16039689. https://doi.org/10.4238/gmr16039689

[19] Bicikliski, O., Trajkovka, F. and Mihajlov, L. (2018) Morphological Characteristics of Some Pepper Genotypes (Capsicum annuum L.) Grown in Conventional and Organic Agricultural Systems: Comparative Analysis. Annual Research and Review in Biology, 28, 1-11. https://doi.org/10.9734/ARRB/2018/43308

[20] Abou Donia, M.A. (2008) Métaux lourds dans les épices et les plantes médicinales égyptiennes et effet du traitement sur leur teneur. Global Veterinaria, 2, 175-181.

[21] Bianchi, P.A., Da Silva, L.R.A., Da Silva, A.A.A., Diniz Santos, P.H.A., Pimenta, S. Sudré, C.P., Erpen-Dalla, Corte L., Gonçalves, L.S.A. and Rodrigues, R. (2020) Biomorphological Characterization of Brazilian Capsicum chinense Jacq. Germplasm. Agronomy, 10, Article No. 447. https://doi.org/10.3390/agronomy10030447 
[22] Yadwad, A., Sridevi, O., Kamatar, M.Y. and Salimath, P.M. (2013) Genetic Bases of Resistance to Thrips and Mites in Chili (Capsicum annum L.). Plant Archives, 9, 801-806.

[23] Syukur, M., Sujiprihati, S. and Yunianti, R. (2010) Diallel Analysis Using Hayman Method to Study Genetic Parameters of Yield Components in Pepper (Capsicum annuum L.). HAYATI Journal of Biosciences, 17, 183-188. https://doi.org/10.4308/hjb.17.4.183

[24] Moreira, A.F.P., Ruas, P.M., Ruas, C.F., Baba, V.Y., Giordani, W., Arruda, I.M., Rodrigues, R. and Gonçalves, L.S.A. (2018) Genetic Diversity, Population Structure and Genetic Parameters of Fruit Traits in Capsicum Chinese. Scientia Horticulturae, 236, 1-9. https://doi.org/10.1016/j.scienta.2018.03.012

[25] Andrade, N.J.P., Monteros-Altamirano, A., Bastidas, C.G.T. and Sorensen, M. (2020) Morphological, Sensorial and Chemical Characterization of Chilli Peppers (Capsicum spp.) from the CATIE Genebank. Agronomy, 10, Article No. 1732. https://doi.org/10.3390/agronomy10111732

[26] Fett, D.D. (2003) Botanical Briefs: Capsicum Pepper. Cutis, 72, 21-23.

[27] Amiot-Carlin, M.J., Caillavet, F., Causse, M., Combris, P., Dallongeville, J., Padilla, M., Renard, C. and Soler, L.G. (2007) Les fruits et légumes dans l'alimentation. Enjeux et déterminants de la consommation. Expertise scientifique collective, synthèse du rapport. Institut national de la recherche agronomique, Paris, $80 \mathrm{p}$.

[28] Blanck, H.M., Gillespie, C., Kimmons, J.E., Seymour, J.D. and Serdula, M.K. (2008) Trends in Fruit and Vegetable Consumption among U.S. Men and Women 1994-2005. Preventing Chronic Disease, 5, Article No. A35.

[29] Johnson Jr., W. (2007) Final Report on the Safety Assessment of Capsicum Annuum Extract, Capsicum annuum Fruit Extract, Capsicum annuum Resin, Capsicum annuum Fruit Powder, Capsicum frutescens Fruit, Capsicum frutescens Fruit Extract, Capsicum frutescens Resin, and Capsaicin. International Journal of Toxicology, 26, 3-106. https://doi.org/10.1080/10915810601163939

[30] Rodriguez-Burruezo, A., González-Mas Mdel, C. and Nuez, F. (2010) Carotenoid Composition and Vitamin A Value in Ají (Capsicum baccatum L.) and Rocoto ( $C$. pubescens R. \& P.), 2 Pepper Species from the Andean Region. Journal of Food Sciences, 75, S446-S453. https://doi.org/10.1111/j.1750-3841.2010.01795.x

[31] Avaloz De La Cruz, D.A. (2007) Faisabilité de la production au Mexique de fromages de chèvre additionnés de piment: Aspects technologiques, sensoriels, sanitaire et économique. Thèse de Doctorat, Institut national polytechnique de Lorraine, Lorraine, $273 \mathrm{p}$.

[32] Kollmannsberger, H., Rodríguez-Burruezo, A., Nitz, S. and Nuez, F. (2011) Volatile and Capsaicinoid Composition of Ají (Capsicum baccatum) and Rocoto (Capsicum pubescens), Two Andean Species of Chile Peppers. Journal of the Science of Food and Agriculture, 91, 1598-1611. https://doi.org/10.1002/jsfa.4354

[33] Bae, H., Jayaprakasha, G. K., Jifon, J. and Patil, B. S. (2012) Variation of Antioxidant Activity and the Levels of Bioactive Compounds in Lipophilic and Hydrophilic Extracts from Hot Pepper (Capsicum spp.) Cultivars. Food Chemistry, 134, 1912-1918. https://doi.org/10.1016/j.foodchem.2012.03.108

[34] Tilahun, S., Paramaguru, P. and Rajamani, K. (2013) Capsaicin and Ascorbic Acid Variability in Chilli and Paprika Cultivars as Revealed by HPLC Analysis. Journal of Plant Breeding and Genetics, 1, 85-89.

[35] Pino, J., Gonzalez, M., Ceballos, L., Centurion-Yah, A.R., Trujillo-Aguirre, J., Latournerie-Moreno, L. and Sauri-Duch, E. (2007) Characterization of Total Capsai- 
cinoids, Colour and Volatile Compound of Habanero chilli Pepper (Capsicum chinense Jack.) Cultivars Grown in Yucatan. Food Chemistry, 104, 1682-1686. https://doi.org/10.1016/j.foodchem.2006.12.067

[36] Hervert-Hernandez, D., Sayago-Ayerdi, S.G. and Goni, I. (2010) Bioactive Compound of Four Hot Pepper Varieties (Capsicum annuum L.): Antioxidant Capacity, and Intestinal Bioaccessibility. Journal of Agricultural and Food Chemistry, 58, 3399-3406. https://doi.org/10.1021/jf904220w

[37] Zimmer, A.R., Leonardi, B., Miron, D., Schapoval, E., Oliveira, J.R. and Gosmann, G. (2012) Antioxidant and Anti-Inflammatory Properties of Capsicum baccatum: From Traditional Use to Scientific Approach. Journal of Ethnopharmacology, 139, 228-233. https://doi.org/10.1016/j.jep.2011.11.005

[38] Sran, T.S., Jindal, S.K. and Chawla, N. (2021) Genotype by Environment Interaction for Quality Traits in Chilli Pepper (Capsicum annuum L). Genetika, 53, 23-49. https://doi.org/10.2298/GENSR2101023S

[39] Kopta, T., Slosar, M., Andrejiova, A., Milos, J. and Pokluda, R. (2019) The Influence of Genotype and Season on the Biological Potential of Chilli Pepper Cultivars. Folia Horticulturae, 31, 365-374. https://doi.org/10.2478/fhort-2019-0029

[40] Bosland, P.W. and Votava, E.J. (2012) Poivrons: Poivrons aux légumes et aux épices. 2sd édition, CABI, Wallingford, Royaume-Uni, Science de la production végétale dans la série horticole, $22 \mathrm{p}$.

[41] Phimchan, P., Techawongstien, S., Chanthai, S. and Bosland, P.W. (2012) Impact du stress hydrique sur l'accumulation de capsaïcinoïdes dans les cultivars de capsicum avec différents niveaux initiaux de capsaïcinoïdes. HortScience, 47, 1204-1209. https://doi.org/10.21273/HORTSCI.47.9.1204

[42] González-Zamora, A., Sierra-Campos, E., LunaOrtega, J.G., Pérez-Morales, R., Ortiz, J.C.R. and García-Hernández, J.L. (2013) Caractérisation de différentes variétés de capsicum par évaluation de leur teneur en capsaïcinoïdes par chromatographie liquide haute performance, détermination de piquant et effet de la température élevée. Molécules, 18, 13471-13486. https://doi.org/10.3390/molecules181113471

[43] Fondio, L., Kouamé, C., Djidji, A.H. and Aïdara, S. (2009) Bien cultiver le piment en Côte d'Ivoire. Centre National de Recherche Agronomique (CNRA), Côte d'Ivoire, $1-4$.

[44] Hakmaoui, A., Zaki, N., Baye, Y. and Ouatamane, A. (2013) Techniques de production du piment rouge (niora) au périmètre irrigué de tadla. Transfert de Technologie en Agriculture, 198, 1-6.

[45] FAO/OMS (World Health Organization) (2017) COMMISSION DU CODEX ALIMENTARUS, Demande d'observations à l'étape 3 sur l'avant-projet de code d'usages pour la prévention et la réduction de la contamination des épices par les mycotoxines. CL 2017/28-CF Février 2017, 1-14.

[46] Institut Agronomique et Vétérinaire Hassan II (IAVH II) / Bulletin de Transfert de Technologie en Agriculture (BTTA) (2013) Techniques de production du piment rouge (niora) au périmètre irrigué de tadla. Transfert de Technologie en Agriculture, 198, 1-6.

[47] Garba, K., Adeoti, K., Hodonou, A., Tidjani, A., Hounhouigan, J. and Toukourou F. (2014) Study of Sanitary of Groundnut Oil and Peanut Cakes from Agonlin Plateau: Identification of Critical Control Points during Groundnut Craft Transformation, Microbiologie Hygiène Alimentaire, 75, 17-21.

[48] Ohin, B., Adeoti, K., Noumavo, A. P., Kouhounde, H. S. S., Garba, K., Tovide, S. N., Ogoua, S., Baba-Moussa, L., Toukourou, F. and Baba-Moussa, F. (2018) Technolo- 
gical Processes Itinerary and Socio-Economic Impact Assessment of Borassus aethiopum Hypocotyles "Agonté" Produced in Centre of Benin Republic. Food and Public Health, 8, 35-41.

[49] Kennao, E., Kumari, A., Singh, M., Hossain, S.A., Das, A., Wasnik, P.K. and Bharti, B.K. (2020) Effect of Drying on Physicochemical Characteristics of Bhut Jolokia (Chilli Pepper). Journal of Food Process Technology, 11, 823-831.

[50] Ghosh, B.C., Jayaraj, R.K., Balasubramanyam, B.V. and Kulkarni, S. (2007) Normalisation des processus et évaluation de la durée de conservation du chhanapodo. Indian Journal of Dairy Science, 60, 322-326.

[51] Nascimento, P.L., Nascimento, T.C, Ramos, N.S, Silva, G.R, Gomes, J.E. and Falcão, R.E. (2014) Quantification, activité antioxydante et antimicrobienne de composés phénoliques isolés de différents extraits de Capsicum frutescens (Pimentamalagueta). Molécules, 19, 5434-5447. https://doi.org/10.3390/molecules19045434

[52] El-Ishaq, A. and Obirinakem, S. (2015) Effet de la température et du stockage sur la teneur en vitamine $\mathrm{C}$ dans les jus de fruits. International Journal of Chemical and Biomolecular Science, 1, 17-21. 